\title{
IS THERE A CONSISTENCY IN THE EU'S APPROACH TOWARDS INVESTMENT ARBITRATION?
}

\author{
Ines Medić ${ }^{1}$ \\ Mia Grgić ${ }^{2}$ (1)
}

DOI: https://doi.org/10.31410/LIMEN.2019.111

\begin{abstract}
The history of the European Union's unease on the anti-arbitration policy is long. It dates back in 2007 and the Lisbon Treaty which transferred competence for concluding treaties from the Member States (MSs) to the European Union. In 2019 it is hard to find someone in legal circles who doesn't know about the famous and controversial Achmea judgment. Court of Justice of the European Union (CJEU) played hard on this topic, although Advocate General and the national court of MSs had different and thoroughly argumented opinions. By this judgment, all arbitration clauses in intra-EU BITs have been invalidated. On the other hand, CJEU didn't offer an adequate alternative for invalid arbitration clauses, nor answered on the question of substantive protection, which is provided by intra-EU BITs. More controversially, in Opinion 1/17 Court declared CETA's provision on dispute settlement valid and EU friendly. The reaction of the MSs almost validated CJEU's intervention into, by then, so carefully built mosaic of investment dispute settlements. Whether it has been given under the pressure of the Commission or at the initiative of MSs, together with the respective judgment, it was an impulsive move. In this Article, the Authors are going to explain how did the Achmea judgment disturbed the internal market and why the past system was more investment-friendly.
\end{abstract}

Keywords: Achmea judgment, Investment arbitration, CJEU.

\section{INTRODUCTION}

E very market is trying to attract investors. From the last decades of the past century, bilateral investment treaties (hereinafter: BIT) are the main tool for attracting investors. Actually, the first BIT was concluded by one of the EU's strongest MS, Germany (Bilateral Investment Treaty between Germany and the Islamic Republic of Pakistan, 1959). According to the EU's data, EU is the main provider and a global destination for the foreign investments (https://ec.europa.eu/trade/policy/accessing-markets/investment/, retrieved: 11 January 2020). That is not a surprise considering the size of the internal market and the power of the economies of some of the strongest MSs. Under such circumstances, as soon as it got the opportunity, the EU has started developing its own investment policy with autonomous European rules.

However, the process was not going smoothly. It took some decades of soft low attempts and the introduction of the new competences under the Lisbon Treaty for the EU to gain exclusive competence for foreign direct investments. Despite it all, it took a Court of Justice of the European Union's (hereinafter: CJEU) judgment to persuade (at least some of) the MSs to terminate their intra-EU BITs. Famous Achmea (Achmea B.V. v. Slovak Republic, C-284/16, hereinafter: Achmea) judgment declared all arbitration clauses in intra-EU BITs invalid. Just like that, with no alternative and with number of questions unanswered.

In this article the authors are going to give an overview of the EU's policy on the matter and try to predict the future of the investment arbitration on European soil.

\footnotetext{
1 Faculty of Law, University of Split, Domovinskog rata 8, 21000 Split, Croatia

2 Faculty of Law, University of Split, Domovinskog rata 8, 21000 Split, Croatia
} 


\section{SHORT HISTORY OF THE EU'S ANTIARBITRATION POLICY}

Although at first sight it might not seem so, even a brief overview of the EU's legislative activities clearly shows that the EU's antiarbitration policy in the field of investment protection dates quite long ago. Precisely, it dates back in 2006 (Ilie, 2018,), but until 2009 and the Treaty of Lisbon the EU's activities in this area were within the ambit of the soft law, at the level of recommendations to the MSs. During these years the Commission's policy was based on the note to the Economic and Financial Committee of the Council (Ilie, 2018). Commission's position amounted to the argument that, upon the accession of the respective MSs to the EU, ,most of the provisions included in the intra-EU BITs have been ,replaced” by the Community law.” (Potesta, 2009, p. 229). Thus, the Commission recommended to the MSs to terminate all intra-EU BITs based on its position that intra-EU BITs are unnecessary at the internal market since the core of the intra-EU BITs (protection of the foreign investors) is now part of the EU's commercial policy based on four freedoms (free movement of goods, services, capital, and labor) and the principle of non-discrimination. Basically, the Commission was trying to convince MSs that two parallel systems regulating foreign investments (one developed under respective BIT and the other one developed as the EU law on investment protection) could lead to the insecurity and uncertainty (Potesta, 2009, p. 229). However, in the beginning, the majority of MSs rejected this recommendation and maintained the existing intra-EU BITs (Stoyanov, 2019, available at: https:/www.allenovery.com/en-gb/global/ news-and-insights/legal-and-regulatory-risks-for-the-finance-sector/europe/increased-enforcement-risk-in-intra-eu-investment-treaty-arbitration, retrieved: 12 January 2020, and Ilie, 2018).

After the failures to prove to the MSs that in case of a clash of the EU law and law based on different BITs the EU law must prevail, the Commission tried the other direction. It acted as amicus curiae in different arbitral proceedings (e.g. Eletrcabel S.A. v. Republic of Hungary, ICSID Case No. ARB/07/19, Micula v. Romania, ICSID Case No. ARB/05/20 or Achmea B.V.v. Slovak Republic, PCA Case No. 2008-13, etc.) trying to prove that arbitral tribunals cannot have jurisdiction over disputes based on intra-EU BITs. Firstly, the Commission tried to argue that all intra-EU BITs are silently terminated and replaced with the EU law, but the arbitral tribunals were not convinced and in number of occasions they argumented that it would be contrary to the provisions of the Vienna Convention on the Law of the Treaties (hereinafter: VCLT) and its provisions on the termination of the treaties (see: Eastern Sugar B.V. (Netherlands) v. Czech Republic, SCC Case No. 088/2004, hereinafter: Eastern Sugar, para. 181). Consequently, most of the Commission's attempts to prove the lack of jurisdiction on behalf of the tribunals were not accepted by the tribunals. More often than not, arbitral tribunals considered that provisions of the BITs on the investment protection could not be superseded and replaced by the EU law, simply because they deal with different matters (e.g. see: Eastern Sugar).

The Treaty of Lisbon has changed, improved and strengthened the EU's position. It gave the EU exclusive competence over foreign direct investments (Treaty on the Functioning of the European Union, Official Journal of the EU C 326, hereinafter: TFEU, Art. 207). Based on that competence, common commercial policy was soon enriched with the new Regulation, establishing transitional arrangements for bilateral investment agreements between the Member States and third countries (Regulation (EU) No 1219/2012, Official Journal of the EU L 351/40, hereinafter: Grandfathering Regulation). This new propulsive force enabled the Commission's second act in the field of the foreign direct investment, i.e. announcement of replacement of old extra-EU BITs with the new ones and Commission's participation in the dispute settlement procedures based on these BITs (see: The Grandfathering Regulation, Preamble rec. 5, Art. 13). Until 2016, EU MSs have concluded 1384 
BITs with third countries (Schacherer, 2016, available at: https://www.iisd.org/itn/2016/08/10/can-eumember-states-still-negotiate-bits-with-third-countries-stefanie-schacherer/, retrieved: 13 January 2020). By the same time Commission has given 93 authorisations to open new negotiations, 41 to open re-negotiations and 21 authorisation to conclude protocol for existing BITs (Schacherer, 2016).

However, the question of intra-EU BIT's remained open, despite the fact that Commission didn't stand still. (for more: Dias Simoes, 2017, pp. 234-303). Namely, in 2010 Commission announced its intentions to build the new EU investment policy in its Communication to the Council, the European Parliament, the European Economic and Social Committee and the Committee of Regions-Towards a comprehensive investment policy (available at: https:/eur-lex.europa.eu/legal-content/EN/ TXT/HTML/?uri=CELEX:52010DC0343\&from=EN, hereinafter: Communication, retrieved: 12 January 2020). It highlighted goals like legal certainty, creation of stable, sound and predictable environment for the investors, openness for investments, etc., but it did not show any serious intention for exclusion of the intra-EU BITs from the common commercial policy, at least as long as they ,remain consistent with the EU policy" (Communication). However, the tone of Communication clearly indicated the Commission's intention to play bigger role in creating investment policy of the MSs.

Already in 2015, under Art. 258 TFEU, the Commission initiated infringement procedures against five MSs (Austria, the Netherlands, Romania, Slovakia, and Sweden) with the formal request for the termination of their intra-EU BITs due to their incompatibility with the Art 351 TFEU (https://www.faegrebd.com/en/insights/publications/2015/7/ecs-infringement-proceedings-for-intraeu-bits-cause-uncertainty-for-investors, retrieved: 13 January 2020) but had a little success in its aim to proclaim intra-EU BITs unnecessary and invalid, since only Romania terminated all its BITs on the unilateral basis (Ilie, 2018). Later this year, due to different objections on disadvantages of investment arbitration (e.g. lack of transparency, inconsistency, inability of the host states to regulate public policy matters without risking arbitration because infringement of the BIT, etc.), the EU has finally agreed on the reform of dispute settlement method in investment matters with the aim of setting up the permanent dispute settlement mechanism called the Investment Court System (https://ec.europa.eu/trade/policy/accessing-markets/investment/, retrieved: 14 January 2020).

In March 2018, the EU council adopted directives authorising the EU Commission to negotiate a convention establishing a court for the settlement of investment disputes (Wyss, 2018, available at: https://www.lexology.com/library/detail.aspx?g=475fa99b-9c5c-4800-bc68-c854cd806525, retrieved: 13 January 2020). In January 2019, in the aftermath of the Achmea, the MSs issued the Declaration on the legal consequences of the Achmea judgment and on the investment protection (available at: https://ec.europa.eu/info/publications/190117-bilateral-investment-treaties_en, retrieved: 12 January 2020, hereinafter: Declaration) proclaiming all intra-EU BITs terminated and announcing new multilateral treaty on this issue (Declaration, para. 5). They also promised to, with regard to ongoing cases, inform sitting tribunals not to accept jurisdiction or issue any awards and to direct investors to hold off of any new intra-EU arbitration proceedings (paras. 1-3).

Separate Declaration was also signed by Malta, Luxembourg, Slovenia, and Sweden, in which they consider inappropriate a priori excluding intra-EU arbitration based on Energy Charter Treaty (hereinafter: ECT) without any CJEU ruling on the matter (https://www.regeringen. se/48ee19/contentassets/d759689c0c804a9ea7af6b2de7320128/achmea-declaration.pdf, retrieved: 12 January 2020). Also, ECT prohibits any reservations on it and EU as well as its MSs and EURATOM gave its ,, unconditional consent to the submission of a dispute to international arbitration" (ECT, Art. 26). Consequently, any decision of the CJEU on the incompatibility of 
the arbitration under ECT with the EU law would conflict with the previously stated will of the EU and its MS (Newing, Alexander, Meredith, 2018). Still, the legal world is uncertain about the EU's intentions at the international level (Newing, Alexander, Meredith, 2018).

But the direction of the revolution was indicated in the Opinion 1/17 of the CJEU on the compatibility of the dispute settlement methods provided by the Comprehensive Economic and Trade Agreement between Canada and EU and its MS (hereinafter: CETA, available at: https://ec.europa. eu/trade/policy/in-focus/ceta/ceta-chapter-by-chapter/, retrieved: 13 January 2020) with the EU law. It seems that the EU as the largest market has a monopoly over this issue and that new multilateral approach is the future of the investment law. The EU gave some notice in the CJEU's Opinion on the compatibility of the CETA rules on dispute settlement with the EU law. The main features of the Opinion may be summarized as follows: ,the mere fact that CETA's ICS stands outside the EU judicial system does not in itself breach the autonomy of the EU legal order" (Croisant, 2019); the principle of equal treatment is also respected since all investors are in comparable situation; the principle of effectiveness will not be affected by the tribunal's decisions and finally, with regard to tribunal's accessibility, the Court stated that, dependent on the Council's commitment, Tribunal will be accessible to ,the most vulnerable users (natural persons and small and medium-sized enterprises)“.

Following the Opinion 1/17 of the CJEU, in October 2019 the EU Commission presented four proposals regarding procedure, conduct and related matters.

However, the turning point did not follow immediately nor it came from the anticipated direction. It was served by the CJEU, in terms of the famous and controversial Achmea decision which in 2018 disturbed the investment policy of the MSs. Namely, by this judgment, all intra-EU BITs are declared invalid. Although the cracks started to appear already in the context of Micula case (Joined Cases T- 624/15, T-694/15 and T-704/15, hereinafter: Micula), no one seem to have predicted such outcome.

\section{ACHMEA AND ITS CONSEQUENCES ON INVESTMENT CLIMATE IN THE EU}

Achmea's case was presented to the CJEU in the stage of the enforcement of the arbitral award. Arbitration proceeding was initiated based on Slovakia-Netherlands BIT, concluded in 1991. Namely, in 2008 the Dutch company (Achmea) commenced an arbitration proceeding against Slovakia. Since the seat of arbitration was Frankfurt, the applicable law (based on the place of the seat of the arbitration) was German law. In 2012 the parties got the award by which Slovakia was ordered to pay the damages to the Achmea, but Slovakia commenced the procedure for setting aside the award (for more see: Uzelac, 2019, pp. 7-30). The case went to the German Supreme Court (Bundesgerichthof, hereinafter: BGH). BGH took a stand that the Slovakia's application was not justified but decided to ask CJEU for preliminary ruling since the CJEU has never considered the compatibility of the arbitration clauses in intra-EU BITs with the EU law (in concreto Art. 267 and 344 TFEU). Advocate General (hereinafter: AG) took the same stand as BGH (available at: https://eur-lex.europa.eu/legal-content/EN/TXT/HTML/?uri=CELEX:62016CC0284\&from=EN, retrieved: 14 January 2020) but the CJEU overruled the AG's Opinion and considered that such arbitration clauses in intra-EU BITs could have adverse effects on the autonomy of the EU law in the MSs (Achmea, para. 59). Namely, the CJEU considered that the EU law is a part of the national laws of the MSs which means that arbitration tribunals also have to interpret and apply some of the main provisions of the EU law (such as provisions 
on the freedom of establishment and free movement of capital). Since arbitration tribunals are not a part of the judicial systems of the MSs they are not allowed to bring questions before the CJEU. Consequently, their awards could endanger the autonomy and efficiency of the EU law (Achmea, para. 42, 43, 45 and 59). Compared to the earlier CJEU's ruling in taxation disputes (C-377/13, Ascendi Beiras Litoral e Alta, Auto Estradas das Beiras Litoral e Alta SA v Autoridade Tributária e Aduaneira) position of the CJEU in Achmea may seem surprising. However, the alleged inconsistency may be justified by the difference between these two cases. The arbitration tribunals dealing with the taxation disputes were at the time part of the judicial system in Portugal (unlike arbitral tribunals in investment disputes) and the dispute was commenced based on the events after the Slovakian access to the EU (unlike the Micula case).

The only thing that is crystal clear regarding the Achmea judgment is that dispute settlement mechanism under the intra-EU BITs is incompatible with the EU law (paras. 32, 58) and that it does not extend to commercial arbitration (paras. 54-55). All the other consequences of the Achmea decision are still unknown. Unfortunately, the decision raises a number of questions, one more important than the other.

First, there are some public international law concerns. Namely, the silence with regard to the VCLT which governs the conclusion, interpretation, validity and invalidity of treaties. Following the provisions of the VCLT, arbitral tribunal cannot decide on the validity of the treaty upon which it bases its jurisdiction. Since it is not bound by the Achmea judgment either it can only accept the treaty as it is and check if the conditions for jurisdiction are in place.

Also, Achmea ruling has no mention of the International Convention for Settlement of Investment Disputes (hereinafter: ICSID Convention) (1966) or the New York Convention on the Recognition and Enforcement of Foreign Arbitral Awards (hereinafter: NYC) (1958) nor of the enforcement of an award rendered under intra-EU BIT. With regard to the enforcement before the EU MS authorities of the award rendered based on the intra-EU BIT, procedure might differ depending on the source of the award. Namely, if the award in intra-EU case is rendered by the ICSID, under the Art 54 of the ICSID Convention the award is to be enforced without any review ,as if it were a final judgment of a court in that State“. Thus, there are no procedural grounds to defend against it, including Achmea ruling. If the award is a non-ICSID award, recognition and enforcement is ruled by the NYC with number of grounds for non-recognition. Of those potentially relevant regarding the Achmea ruling (nullity of the arbitration agreement, Art $\mathrm{V}(1)(\mathrm{a})$ and public policy, Art V(2)(b)) none can actually be used since the Achmea dealt with the dispute settlement mechanism, which cannot be declared invalid by the national authority (due to the VCLT) nor is a part of public policy defence (under the NYC). Thus, if applied without any policy influence, NYC does not leave the room for the reception of Achmea. However, national courts of the EU MSs might decide to refuse to give effect to such awards.

Second, there is a question of the scope of the decision. Does it encompass only particular intra-EU BIT or all intra-EU BITs? There is an express declaration that Achmea applies to ,a provision in an international investment agreement concluded between MSs, such as" the one under examination (para. 49). Although referring to the BIT in question, it is obvious that the judgment's implications encompass all intra-EU BITs.

There is also a question of jurisdiction stemming from an arbitration agreement or intra-EU investment arbitration proceedings already pending? Achmea does not offer any answer to the 
question whether the incompatibility of the arbitration clause with the EU law deprives the arbitral tribunal of its jurisdiction. Due to the fact that tribunals are outside the scope of EU's competence and the provisions of the VCLT (art. 54), answer should be negative.

Furthermore, it is not clear whether and how Achmea relates to multilateral agreements. Is it applicable to investment treaties to which EU itself is a party like ECT, or to BITs between EU Member States and third countries or the ICSID Convention? If yes, on what grounds? What impact does it have for the future MSs? Is termination of the existing BITs going to be a precondition of their accession? Due to „sunset clauses“ it will not affect disputes which arose before accession. There is less clarity with regard to investments and/or disputes arising after that date.

\section{ACHMEA'S FOLLOW-UP}

In 2019, after turbulences caused by Achmea ruling, General Court of the EU (hereinafter: GCEU) presented the silver lining (Bakos, 2019). Micula decision, initially ICSID case (Ioan Micula, Viorel Micula, and others $v$ Romania, ICSID Case No. ARB/05/20), became one of the most prominent decisions of the GCEU). It dealt with the ratione temporis application of the EU law. In answering the question whether the compensation rendered by the arbitration tribunal can be considered as the illegal state aid the GCEU took the negative stand because all considered events took place before Romania's accession to the EU (Micula case, para. 109). Such ruling is of the utmost importance to the foreign investors in young MSs, such as Romania, Slovenia or Croatia and for the investors in old MSs in which so-called „sunset clauses“ are still protecting foreign investors. Still, the decision rendered by the GCEU is subject to the appeal procedure before the CJEU, so it remains to be seen how this saga ends. At the moment, Micula case is pending before the UK Supreme Court and according to some predictions waiting for the Brexit come through (Dimitrov, 2019, available at: http://arbitrationblog.kluwerarbitration. com/2019/10/18/navigating-through-stormy-seas-the-uk-supreme-court-hears-the-micula-case/, retrieved: 14 January 2020). In any case, it will provide a landmark of the post-Brexit investment climate in the UK. Most of the MSs consider Achmea inapplicable in the case of the intra-EU arbitration, but there is no consensus within the EU on this topic. Namely, Hungary gave separate Declaration in which it does not recognize the effects of the Achmea decisions on the intra-EU arbitrations based on ECT (Kohegyi, Gans, 2019, available at: https://www.dlapiper.com/de/germany/insights/publications/2019/01/legal-consequences-of-the-achmea-decision/, retrieved: 14 January 2020, and https://www.regeringen.se/48ee19/contentassets/d759689c0c804a9ea7af6b2de7320128/achmea-declaration.pdf, retrieved: 14 January 2020 ).

Consequently, there are cases based on intra-EU BITs in which states tried to rely on Achmea, like in ICSID Case No. ARB/12/39 Gavrilović v. Croatia, based on Austrian-Croatian BIT. Despite the fact that Croatia invoked the Achmea argument, it was rejected because the objection was not raised in due time (Uzelac, 2019, p. 15). On the other hand, in number of cases tribunals considered the Achmea decision irrelevant with regard to treaty obligations of states and decided on its non-applicability with regard to jurisdictional objections (e.g. in UP and C.D. Holding Internationale v. Hungary, ICSID Case No.ARB/14/1, Tribunal considered that ,Achmea cannot excuse non-compliance with public international law“ (Dragiev, 2019, p. 2).

There are also some pending proceedings regarding the ECT. Since the CJEU did not take a stand on the compatibility of arbitration clauses in multilateral agreements in which the EU (alongside the MSs) is the party, their current status remains uncertain. So far, the most com- 
prehensive ruling on the matter is the Vattenfall v. Germany, ICSID Case No. ARB/12/12 (hereinafter: Vattenfall). In its ruling the tribunal refused to accept the stand that the EU law makes a part of general international law. Also, in Masdar Solar \& Wind Cooperative U.A. v Kingdom of Spain, ICSID Case No. ARB 1/14/1 (hereinafter: Masadar) the tribunal rejected applicability of the Achmea ruling on ECT (Uzelac, 2019, p. 14 and Beham, 2020).

\section{CONCLUSION}

The EU judicial system has unique features. It is best described by para. 70 of the Opinion 1/09 (European and Community Patent Court) according to which the EU has established ,a complete system of judicial remedies' for individuals, MSs, the EU institutions and its agencies and bodies“. Within that system, the special characteristics of EU law are preserved, the EU law is interpreted uniformly and consistently, the EU law is fully applied and individual's rights are judicially protected“" (Ankersmit, 2016, p. 49.). Consequently, according to para. 183 of the Opinion 2/13 (Accession to the ECHR), the EU may subject itself to other international courts only ,if the indispensable conditions for safeguarding the essential character of those powers are satisfied and there is no adverse effect on the autonomy of EU legal order" (Opinion 2/13, para. 183). Alteration of this system is only possible by changing the Treaties.

Despite its many advantages with regard to investors, the ISDS clearly does not satisfy the above conditions. First and foremost, there is no requirement on behalf of the parties to exhaust domestic remedies. Moreover, „fork in the road“ clause requires investors to choose a single avenue of judicial relief and prevents them from switching forums after they started the proceedings. Also, tribunals are not a part of national judiciary and as such are not entitled to refer the preliminary question to the CJEU. Thus, if parties opt for arbitration, the tribunal may come to a different interpretation of EU law (e.g. regarding non-discrimination or FET standard) which adversely affects carefully established European judicial system and the autonomy of EU legal order.

But besides looking at the Achmea from the standpoint of EU law one might also take a look from the standpoint of international arbitration. Under public international law, BITs remain valid and binding unless they expire or are replaced with the new agreement relating to the same subject matter. Consequently, arbitral tribunals are not bound by the Achmea nor have they been convinced by the Achmea. Many of them have rejected the jurisdictional objection and proceeded with the case. Besides, most BITs contain „sunset clauses“ which bind a state to BIT for a long period beyond the termination date.

From the parties' standpoint, relying on the existing intra-EU BITs has never been more uncertain. There are several hurdles to overcome regarding the arbitration tribunals as well as state courts. In order to mitigate the disadvantages, before the dispute arises, they may consider cross-border group restructuring and/or investing through corporate structures located outside of the EU. Once the dispute arises it is already too late to do that and the choice amounts to arbitral tribunal or a state court. Post Brexit UK and/or Switzerland might pop up as the obvious jurisdictions for restructuring and/or bringing BIT disputes.

However, looking back at the Commission's activities, even long before the Lisbon treaty, it is more than obvious that ,the current-model of investor-state dispute settlement has been under

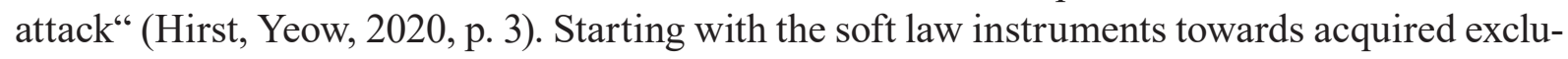


sive competence and regulations and directives aimed towards establishment of the permanent investment court system, one cannot notice that there is a consistency in the EU's approach towards investment arbitration. And that that approach is antiarbitration one. An insight into investment treaties recently signed or negotiated between the EU and third countries (e.g. India, Japan, Mexico, Singapore, Vietnam, etc.) (see: http://www.trade.ec.europa.eu, retrieved: 15 January 2020) only confirms this view. CETA and its investment chapters (e.g. two-tiered investment court system) may be regarded as de facto model for other EU bilateral investment treaties. Sooner or later all of pre-existing intra-EU BITs will also be replaced with a single multilateral agreement with the same model. The ultimate goal of the introduction of the same model and at all levels is to achieve coherency in the EU investment policy. MSs BITs (either intra-EU or with the third states) aimed at promoting their specific interests vis-a-vis negotiating partners certainly do not fit this scheme (see: https://ec.europa.eu/trade/policy/accessing-markets/investment/, retrieved: 14 January 2020).

To conclude, as the time goes by investment arbitration on the territory of EU will most likely lose its importance and be replaced with some sort of a court system. Having in mind parallel strengthening of litigation and mediation as an alternative to commercial arbitration it is safe to say that arbitration in general may easily loose its popularity.

\section{REFERENCES}

\section{Articles}

Ankersmith, L., (2016), The Compatibility of Investment Arbitration in EU Trade Agreements with the EU Judicial System, Journal for European Environmental and Planning Law, April 2016, pp. 46-63.

Bakos, A.C., 2019, Schrodinger's Investment: the EU's General Court Considered that the Compensation Ordered by the Micula Tribunal is not a form of State Aid (Although it Might as Well Have Been, retrieved from: https://efilablog.org/2019/06/26/schrodingersinvestment-the-eus-general-court-considers-that-the-compensation-ordered-by-the-micula-tribunal-is-not-a-form-of-state-aid-although-it-might-as-well-have-been/, retrieved: 15 January 2020.

Beham, M., Prantl, D., 2020, January 7, Intra-EU Investment Reform: What Options for the Energy Charter Treaty?, Kluwer Arbitration Blog, retrieved from: http://arbitrationblog. kluwerarbitration.com/2020/01/07/intra-eu-investment-reform-what-options-for-the-energy-charter-treaty/, retrieved: 12 January 2020.

Croisant, G., 2019, April 30, Opinion 1/17- The CJEU confirms that CETA's Investment Court System is Compatible with EU Law, Kluwer Arbitration Blog, retrieved from: http://arbitrationblog.kluwerarbitration.com/2019/04/30/opinion-117-the-cjeu-confirms-that-cetasinvestment-court-system-is-compatible-with-eu-law/?print=print, retrieved: 15 January 2020.

Dimitrov, I., 2019, October 18, Navigating Through Stormy Seas: The UK Supreme Court Hears the Micula Case, Kluwer Arbitration Blog, retrieved from: http://arbitrationblog.kluwerarbitration.com/2019/10/18/navigating-through-stormy-seas-the-uk-supreme-court-hearsthe-micula-case/, retrieved: 14 January 2020.

Dias Simoes, F. (2017). A Guardian and a Friend? The European Commission's Participation in Investmnet Arbitration, Michigan State International Law Review, Vol. 25.2, 2017, pp. 234-303. 
Dragiev, D., 2019, January 16, 2018 In Review: The Achmea Decision and Its Reverberations in the World of Arbitration, Kluwer Arbitration Blog, retrieved from: http://arbitrationblog. kluwerarbitration.com/2019/01/16/2018-in-review-the-achmea-decision-and-its-reverberations-in-the-world-of-arbitration/, retrieved: 15 January 2020.

Hirst, P., Yeow, M. (2019). International arbitration: Current trends and what to expect in 2020 and the years ahead, 2020, retrieved from: https://www.lexology.com/library/detail.aspx?g=1014006f-0259-435d-819b-0c099a4dd53f, retrieved: 15 January 2020.

Ilie, L., 2018, January 21, What is the Future of Intra-EU BITs?, Kluwer Arbitration Blog, retrieved from: http://arbitrationblog.kluwerarbitration.com/2018/01/21/future-intra-eu-bits/ , retrieved: 14 January 2020.

Kohegyi, D., Gans, S. K., 2019, January 19, EU Member States issued a joint declaration on the legal consequences of the Achmea decision, retrieved from: https://www.dlapiper.com/ de/germany/insights/publications/2019/01/legal-consequences-of-the-achmea-decision/, retrieved: 15 January 2020.

Newing, N., Alexander, L., Meredith, L., 2018, April 28, What Next for Intra-EU Investment arbitration? Thoughts on the Achmea Decision, Kluwer Arbitration Blog, retrieved from: http://arbitrationblog.kluwerarbitration.com/2018/04/21/what-next-for-intra-eu-investment-arbitration-thoughts-on-the-achmea-decision/, retrieved: 15 January 2020.

Potesta, M. (2009). Bilateral Investment Treaties and the European Union-Recent Developments in Arbitration Before the ECJ, 8 Law \& Practice International Courts \& Tribunals, pp. 225-245.

Schaherer, S., 2016, August 10, Can EU Member States Still Negotiate BITs with Third Countries?, retrieved from: https://www.iisd.org/itn/2016/08/10/can-eu-member-states-still-negotiate-bits-with-third-countries-stefanie-schacherer/, retrieved: 15 January 2020.

Stoyanov, M., 2019, November, Increased enforcement risk in intra-EU investment treaty arbitration retrieved from: https://www.allenovery.com/en-gb/global/news-and-insights/legal-and-regulatory-risks-for-the-finance-sector/europe/increased-enforcement-risk-in-intra-eu-investment-treaty-arbitration, retrieved: 12 January 2020.

Uzelac, A. (2019). Why Europe should reconsider its anti-arbitration policy in investment disputes, Access to Justice in Eastern Europe, Issue No. 1(2), pp. 6-30, doi: https://doi. org/10.33327/AJEE-18-2.1-a000008.

Wyss, W. 2018, Achmea-Earthquake - Time to Consider a Swiss Solution, retrieved from: https:// www.lexology.com/library/detail.aspx?g=475fa99b-9c5c-4800-bc68-c854cd806525 , retrieved: 13 January 2020.

\section{European Union Law}

Treaty on the Functioning of the European Union, Official Journal of the EU C 326

Communication to the Council, the European Parliament, the European Economic and Social Committee and the Committee of Regions-Towards a comprehensive investment policy, available at: https://eur-lex.europa.eu/legal-content/EN/TXT/HTML/?uri=CELEX:52010DC0343\&from=EN, retrieved: 12 January 2020

Declaration of the Representatives of the Governments of the Member States on the Enforcement of the Judgment of the Court of Justice in Achmea and on Investment Protection in the European Union, available at: https://www.regeringen.se/48ee19/contentassets/ d759689c0c804a9ea7af6b2de7320128/achmea-declaration.pdf, retrieved: 12 January 2020

Regulation (EU) No 1219/2012 of the European parliament and of the Council of 12 December 2012 establishing transitional arrangements for bilateral investment agreements between Member States and third countries, Official Journal of the EU L 351/40 


\section{Treaties}

Comprehensive Economic and Trade Agreement between Canada and EU and its MS available at: https:/ec.europa.eu/trade/policy/in-focus/ceta/ceta-chapter-by-chapter/, retrieved: 13 January 2020

Energy Charter Treaty, 1994

International Convention for Settlement of Investment Disputes, 1965

New York Convention on the Recognition and Enforcement of Foreign Arbitral Awards, United Nations, 1956

Vienna Convention on the law of the treaties, United Nations, 1969

\section{Case Law}

Achmea B.V. v. Slovak Republic, C-284/16

Ascendi Beiras Litoral e Alta, Auto Estradas das Beiras Litoral e Alta SA v Autoridade Tributária e Aduaneira, C-377/13

Micula case, Joined Cases T- 624/15, T-694/15 and T-704/15

Opinion 1/09 (European and Community Patent Court)

Opinion 2/13 (Accession to the ECHR)

Achmea B.V. v. Slovak Republic, PCA Case No. 2008-13

Eastern Sugar B.V. (Netherlands) v. Czech Republic, SCC Case No. 088/2004

Eletrcabel S.A. v. Republic of Hungary, ICSID Case No. ARB/07/19, Micula v. Romania, ICSID

Case No. ARB/05/20

Gavrilović v. Croatia, ICSID Case No. ARB/12/39

Ioan Micula, Viorel Micula, and others $v$ Romania, ICSID Case No. ARB/05/20

Masdar Solar \& Wind Cooperative U.A. v Kingdom of Spain, ICSID Case No. ARB 1/14/1

UP and C.D. Holding Internationale v. Hungary, ICSID Case No.ARB/14/1

Vattenfall v. Germany, ICSID Case No. ARB/12/12

\section{Web}

https://www.faegrebd.com/en/insights/publications/2015/7/ecs-infringement-proceedings-for-intraeu-bits-cause-uncertainty-for-investors, retrieved: 13 January 2020

https://ec.europa.eu/trade/policy/accessing-markets/investment/, retrieved: 14 January 2020

https:/eur-lex.europa.eu/legal-content/EN/TXT/HTML/?uri=CELEX:62016CC0284\&from $=\mathrm{EN}$, retrieved: 14 January 2020

https://www.trade.ec.europa.eu, retrieved: 15 January 2020

https://ec.europa.eu/trade/policy/accessing-markets/investment/, retrieved: 14 January 2020

https://ec.europa.eu/trade/policy/accessing-markets/investment/, retrieved: 11 January 2020 